\title{
Islamic economy as an alternative solution to managing economic crisis: Some fashionable case studies of Iran, Malaysia Saudi Arabia
}

Hashim Sabo Bello

Department of Business Administration and Management, School of Management Sciences, Abubakar Tatari Ali Polytechnic Bauchi, Bauchi State, Nigeria

Nura Ahmad

Department of Islamic Studies, School of Art and Social Sciences, Aminu Saleh College of Education Azare, Bauchi State, Nigeria

\section{Ibrahim Suleiman Galadima}

Department of Islamic Studies, A.D. Rufa'I College of Legal \& Islamic Studies, Misau, Bauchi State, Nigeria

\begin{abstract}
This review paper examined some economies derives from Islamic value premise in nations such as Iran, Malaysia, and Saudi Arabia as alternative solutions to economic crisis emanating from conventional economies. In today's world of investment and finance, many proponents of Islamic finance (a related branch of Islamic Economics) believe that Islamic finance is a more stable institution as it was virtually unaffected by the financial crisis of 2008 and to some extend enjoys a recent success in the financial market that has awakened the interest of investors both inside and outside of the Islamic community. Nowadays, the global economies take into cognizance the relevance of Islamic finance, in this manner the Islamic banking exists beyond the Muslim world and has recently gained traction in the Western market i.e. France and the United Kingdom have contributed heavily to the global assets in Islamic finance as has the United States. In 2013, the British government established the Islamic Finance Task Force with the goal of making London a base for Islamic finance outside of the Muslim world. Thus this paper believe that the Islamic economics provide the need of the hour to unite the various segments of society in the conviction that Islamic finance is an alternative sustainable solution to the economic crisis as of 2008 caused by reckless economic strategies that lose sight of the human aspect amid the expansion process. The overall recommendation of this paper is that, once Islamic finance as an ethical finance is properly put into practice in our economies, more people would apply for it, whereat such economies might stand to take advantage of the beneficial social goals of Islamic economics in line with the trends, people's needs and aspirations as well as the development imperatives to define the modern economic and social sciences.
\end{abstract}

Key words: Contemporary, Islamic economics, Iran, Malaysia, Saudi Arabia.

JEL Classification: O50, P00.

(C) The Authors, 2018. This article is published with open access at Sumy State University.

\section{Introduction}

Since the failure of the centralized economic system of the East in the 1980s, the efforts of economists, experts, policymakers and governments around the world have been focused on strengthening market forces to achieve optimal economic growth and sustainable development at national and global levels. However, despite some trivial developments, market forces have failed to achieve balanced and equitable growth, not only at individual countries' level but also regionally among both developed and developing countries. While the capitalist system, canonized at Bretton Woods in 1944, allowed a free hand to the capitalist countries and within them the firms and individuals to maximize their profits with minimal consideration of the human aspects, norms and ethics, the post-Bretton Woods system, based on excessive creation of monies, particularly the US Dollar, resulted in "oceans" of poverty around the world (Ayub, 2007).

The Religion of Islam has given a humane and realistic prescription of ways to tackle imbalances in the conventional system. Its central teachings are unprecedented in this area and its care for humanity. It provides laws and the legal framework for the resolution of poverty by offering these practical and realistic policies and operational mechanisms to meet basic human needs while narrowing the gap between the rich and poor. Islam focuses on developing not only the spiritual needs of the individual but also the resources or endowments of the earth for the benefit and welfare of all human beings, to whom everything on earth (and in the heaven) has been made subservient. It proposes solutions to all human and societal problems. Some of these 
solutions are the responsibility of the state (government), some are to be fulfilled by the larger society; others are the responsibility of the individual; and some are jointly shared obligations of these three entities (Lawal, et al, 2016).

Islamic economics and finance holds great potential and appeal for achievement of economic growth with social justice. Particularly, in the present time when countries across the world are growing but their financial and economic progress has been uneven and achieved at the cost of moral and social decline. Moreover, the repercussions of the moral, social, economic and financial rise and fall of regions are no longer isolated but can be felt globally. In this scenario, the need for developing inclusive and sustainable Islamic economic and financial systems becomes much more important (Omar, 2015). With this perspective, the present study focuses on: (i) further expression of the fundamental concepts and methods of Islamic economics, (ii) analysis of the workings of fiscal and monetary policies in Islamic context, (iii) analysis of socio-economic development trends in conventional economy that have caused serious systematic problems, and (iv) solutions to modern economic crisis from the Islamic perspective.

\section{Methodology}

This study used both descriptive and explanatory, the methodology is Narrative-Textual Case Study (NTCS) method, which is preferred because of the absence of sequential data related to Islamic economics towards managing economic crisis in the modern world. NTCS is a social science research method that employs intensively, the information, data and academic materials made available and easily accessible by information and communication technology facilities such as intranet, internet, World Wide Web, online databases, elibraries, etcetera. The choice of this method is informed by the fact that NTCS combines the use of quantitative and qualitative observation, text content analysis and available official statistics in different proportions for problem-solving or problem-identification depending on the objectives of the research. This research study is basically non-empirical, but rather descriptive, since information is collected from the secondary source only. We used such appropriate technique in order to climb some salient points that will help in reaching an intensive analysis and conclusion which can pave leeway to resourceful and acceptable recommendations.

\section{Literature review and conceptual issues}

Since time immemorial religion guide the human beings towards attaining success in every sphere of life in this world and in the life thereafter. Islam is one of the greatest religions of the world and about 1.2 billion people are following this great religion. The Islamic Sharia regulations address all facets of life and the ultimate objective is to establish a just and equitable society for the mankind. One of the significant developments in the Muslim world during the last 50 years is the emergence of Islamic banking, which has appeared as a powerful movement. Although some attempts to reorganize banking activities along the Islamic lines go back to the early 1960's, the concept of Islamic banking is even older. In fact, the strong disapproval of interest by Islam and vital role of interest in the modern commercial banking system led Muslim thinkers to explore the ways and means to organize commercial banking on an interest free basis. However, for quite a long time, the idea of Islamic banking remained just a wishful thinking (Umar, et al., 2010).

Economic thinking from Islamic perspective is not a new phenomenon. Even before the birth of the formal conventional economics discipline, several Muslim scholars have written on the economic and social issues of their time and provided policy advice to the rulers and guidance to the masses. Among the fourteenth century academicians and policy advisors Ibn Khaldun's name (1332-1406 AD) appear prominently, for he not only explained many of the economic phenomenon that present-day economists discuss but also put forward a complete theory of dynastical and social change in which social and economic factors interact to explain the dynamics of the rise and fall of nations, dynasties, cities, societies and businesses (Ali, 2015). The early opinion building as well as the later technical literature on the subject of Islamic economics has greatly contributed to the promotion of this line of inquiry. However, Islamic economics has not yet achieved a level to become a discipline that is able to create a paradigm shift in the way of thinking and policymaking. The need is therefore not only to develop the theory but also to link the theory with policymaking. This transition would also require yardsticks and measuring devices to gauge the social, economic, and financial progress defined in congruence with Islam.

Mawdudi resurfaced the popularity of IE as a tool for identity formation, but implied in all of its iterations is the importance as a prescription for cognitive dissonance between traditionalism (Islam) and modernity (West- 
ernization). The monetary gains from Islamic economics remain disputable, as does the success of these economic tools in contributing to a modern Muslim identity. As for its future, Kuran summarizes the legacy of IE as one potentially allowing Muslims to overcome suspicions of Western intentions; an addition to the political goals of Islam; comfort to modern Muslims trying to navigate today's globalized world; or "paradoxically, its revitalization of the goal, taken for granted by leading Muslim thinkers during much of the twentieth century, of keeping economic ideas, practices, policies, and institutions outside the realm of religion" (Kuran, 2004). With the power of petrodollars weakening, the number of Muslims growing, the recovery of the world market after the 2008 financial crisis, and the increased attention to Islamic politics by Western nations, research into the function of IE as orthopraxy and as an alternative economic model will only continue to rise. Yet it remains to be seen if Islamic economics can continue to maintain its original objective of unifying the Muslim population.

The economic system of any country or society evolves to meet the needs of its members. By and large, the economic system of any Islamic country or society evolves to meet the needs of its members towards beneficial economic and social goals. For instance, the cash disbursement of Sadaqat, creation of Auqaf, organization of education and health services for the poor, contribution (voluntary) to state's defense needs, construction and maintenance of mosques, provision of shelter and meals to the way-farers and various forms of charitable activities fall within this sector. To this, we may add that part of Zakah, which may be left for assessment and distribution to the individual assessee - we mean Zakah on Amwal-Batinah (as specified, for instance, in recent Pakistan legislation). Empirical and historical evidence suggests that substantial economic and financial resources have passed through this sector in Muslim countries. The volume of the economic resources flowing through the third sector will be a function of the state of Taqwa of an Islamic community. It will be, so to say, a barometer of the state of moral health of the Ummah. It will be distinct from the public sector in as much as it will be totally free from any element of compulsion. Even in an Islamic society state operation will in effect be compulsive in nature even if overall design may be decisively moral and religious. Moreover, there is nothing wrong if the public sector is actuated by economic benefit and aims at maximization of profit or of eventual social good. But the third sector will lose all, if it aims at economic benefits (Islamic Banker Limited, 2018).

\section{Conventional economics as a recipe for exploitation}

Nowadays the banks play a significant role in our society, and it is not even possible to imagine the life without banks, in other words the banks have become a blood vein of our economy. In order to stimulate the economy of any specific country the government does this via banking system by using "Monetary Tools". Moreover, all of the finance and business transactions that we are being involved in are done through the banks. However, not only advantages have come out from conventional banking system, but disadvantages as well. As we are witnessing, financial and economic crisis has been occurred mostly due to Conventional Banking System recently. The frequency of happening of such financial crisis has started since existence of Capitalistic system in which the interest rate and speculative transactions are allowed. The Capitalism has been existed since 19th century. The governments and central banks have been striving making economy to work better off after each crisis by applying "Monetary Tools" but their goals didn't reach final stages of its completion (Alimshan, 2011).

Excessive debt and its servicing are the striking features of the interest-based mechanism: yesterday's debt can be repaid by taking out more debt today. It is not only stifling economic growth but also crippling the efforts made by the World Bank, IMF and other donors to reduce poverty in poor countries. It also distorts the payments systems, on account of which the concern for just and fair incomes and earnings is being accorded the least consideration. No one cares who is going to pay the debt: which future generations and from where? This kind of behaviour - avoiding the payment of currently owed debt - is not acceptable under any divine religion. In Islamic Shar ${ }^{-}{ }^{\prime}$ ah, debt liability is subject to strict accountability on the Day of Judgement (Ayub, 2007). Not long ago, the world witnessed a crisis that created doubt in the foundation of capitalism. As it abates, the world economy had witnessed a long period of economic meltdown, with nothing less than $\$ 3$ trillion as bailouts and injections of liquidity to reduce the intensity of the crisis. According to Ben Barnanke, chairman of the Board of Governors of the US Federal Reserve, he was of the opinion that the root cause of the crisis is attributable to the sub-prime mortgage crisis in the US which was basically the result of excessive and imprudent lending banks (Folami, 2011). 
At the other side of the divide, a renowned economist, Prof. Bade Onimode faulted Bernanke's submission as an "icing on the cake". In his work, Africa in the world of the $21^{\text {st }}$ Century, he posited that "the collapse of the world commodity export trade forced the third world countries into a foreign debt crisis. This has been used by the west for draining much needed foreign exchange into foreign debt servicing- situations in which many African countries have repaid their initial foreign loans more than four times over and still owe more than they borrowed initially". He reiterated that by the "1960, rising US deficit financing of the Vietnam War as well as expanding social welfare programmes started putting additional pressures on the global financial system. This required the Gold Pool of the 1960", from which France under de Gaulle pulled out in 1968. As the problem persisted, the pound sterling was devalued in 1967, and this was followed in the 1970s by widespread high inflation, competitive currency depreciation and financial disorders (Folami, 2011).

Former President Obasanjo, speaking in 2000 about Nigeria's mounting debt to international creditors said, "All that we have borrowed up to 1985 was around US\$5 billion, and we have paid about US\$16 billion. Yet we are still being told that we owe about US\$28 billion came about because of the injustice in the foreign creditors' interest rates. If you ask me what the worst thing in the world is, I will say it is compound interest" (Folami, 2011). The economic problems of underdeveloped countries (UDCs) have emanated largely from their excessive debt accumulation. The cost incurred in the form of interest has to be paid by successive governments through increasing rates, taxes and charges on consumption goods and utilities. For servicing the debts, governments raise taxes without providing any socioeconomic amenities or quid pro quo. Their foreign exchange earnings, including export proceeds and remittances of expatriates, are also consumed by debt servicing (Ayub, 2007).

It is evident from the world financial crises, that the world today is experiencing quite a number of economic problems as a result of interest based banking system. These catalogues of problems range from massive poverty, social and economic injustice, gross inequalities in the distribution of income and wealth thus breeding high rate of employment, economic instability, inflation, high costs of doing business and erosion of the real value of monetary assets to mention but a few. All these impediments trace their origin from interest which most conventional banking system are well known to be addicted with. Interest in Islam, apart from it being in conflict with the value system of Islam, it is becoming a rampant phenomenon in the Muslim world, thereby, causing strong decadence in our Islamic spiritualism and so also having the myriad influence of other economic and social menace or upheavals (Abdulkadir \& Murtala, 2016).

This has led to an ever-increasing share of risk-free capital, vis-à-vis risk-based capital and business, resulting in business failures, unemployment and, ultimately, gross inequalities of income and wealth. It has exerted disastrous effects by reinforcing the tendency towards wealth accumulation in fewer hands together with large-scale hunger and poverty. The unproductive and wasteful spending both by individuals and governments, which the interest based mechanism and easily available credit have the tendency to promote, has led to a decline in savings, real investments and employment opportunities. The system, combined with inflation, becomes a recipe for economic instability and chaos. This affects the poor and the middle class, who together comprise the major part of the population, and thereby the level of national savings, leading the economies into a vicious circle of poverty and gross injustice (Ayub, 2007).

\section{Forward-thinking on value premise of the Islamic economic system}

Since 2008, given the global financial crisis after crisis, millions of people all over the world are suffering directly and / or indirectly, whilst looking for alternatives to the conventional modes of banking, financing and investments that can portray ethics and fair dealings. These millions of people who are looking for an alternative system of banking and finance are yet to explore the benefits, opportunities and growth potentials of the Islamic banking and finance industry. Islamic finance, in fact, can promote a balance between the social and economic aspects of human society, the self and social interests and between the individual, family, society and the State. It can effectively address issues like income distribution and poverty alleviation, which capitalism has not been able to address. At the global level, it may be helpful in eliminating the sources of instability, thus making the world a happier place with harmony among followers of various religions (Ayub, 2007). Recent development trends in conventional economy have caused serious systematic problems. It is a violation towards the goal of the implementation of economic activities themselves. The intentions of economy are not only to protect the wealth (hifdzu-1-maal), but also to protect life (hifdzu-n-nafsi) and descendant (hifdzu-n-nasli). Therefore, it demands a fundamental correction (Budiarto, et al., 2016). 
The grim situation found with the conventional economies is not limited to the poor or the least developed countries in Africa, Asia and other areas of the planet. Inequity has become the hallmark and the most serious problem facing mankind in all societies. Masses of people in almost all emerging/developing, Islamic and non-Islamic, and even developed and industrialized economies are facing the same fate. The interest-based financial system is a major hurdle in achieving distributive justice. It is creating unrepayable debt - making a class of people richer and leaving others poorer and oppressed. So, this call for the increasing needs of a paradigm shift to an Islamic banking (a free interest-based financial system) in the poor or the least developed countries in Africa, Asia and other areas of the planet. According to Siddiqui (2004); Obeidullah (2005); Dogarawa \& Bello (2014) cited in Mustapha \& Muhammad (2016), the central aspect of Islamic banking is the absence of interest but there are other social and ethical features such as aiding a more equitable distribution of income and wealth and avoiding undesirable businesses. In line with this thinking, Qutb (2000 cited in Mustapha \& Muhammad, 2016) posited that, Islamic banks are expected to contribute positively towards the achievement of a pattern of growth for the eradication of poverty, equitable distribution of income and wealth and sufficient opportunities for gainful employment. As a matter of fact it is justice and fairness that the prohibition of riba (interest) is perceived to be aiming at.

It's obvious that, almost all present governments spend huge amounts of money on social security nets, but that expense does not tend to mitigate the ill effects of the injustice inflicted by the tools of conventional economics and finance and the resultant iniquitous distribution of income and resources by unhindered market forces. Imbalances created by the system as a whole cannot be corrected only by a government's selective spending; it rather leads to moral hazard in a number of socio-economic directions. Compared with the problems created by the system, such social welfare activities cannot cater to the needs of the millions of poor or the vulnerable groups in any society. In addition to strengthening, restructuring and expanding the social safety nets to provide support to the deserving segments of society, there must be a big change in the system at a broader level so that weaker groups can get their due share at the stage of production and distribution of wealth and assets among various factors of production (Ayub, 2007). Taking the above into account, one could ask, does the Qur'an hold the answer to achieving a fairer world economy? Though wealth creation is the key goal taught by top businessmen, social impact is considered to be a more fulfilling outcome for others. Money is not timeless, but what you do with that money can be. The light you instill in the uneducated, the medicine you provide to the ill, or the food and water you provide to the malnourished is far more enduring than the car you drive or the house you buy. Most advocates of social entrepreneurship believe that creating a business with a social impact leaves much more than just a humble footprint behind.

The concept of social entrepreneurship however is not new despite the recent rise in press coverage. It has existed since the 6th century and one particular group was taught the importance of such business: Muslims. Muslims live their lives in accordance to the teachings of their founder, Muhammad, who led his life as a humble merchant and was the "trustworthy one" by all those who knew him. His teachings and examples of business dealings were strongly linked to humanitarian values where the poor, the sick and orphans took precedence. He acknowledged the suffering of people in surrounding environments and continually created solutions for them while creating a system that would ensure their care long after his passing. The mention of Muhammad is significant to know how today's Muslims are encouraged to create wealth; supporting the notion of an existing link between Islamic business and social enterprise. According to Sir Zafrah Khan, the former Pakistani politician and diplomat, the Holy Qur'an states (59:8), "the object of the Islamic economic system is to secure the widest and most beneficent distribution of wealth through institutions set up by it and through moral exhortation. Wealth must remain in constant circulation among all sections of the community and should not become the monopoly of the right" (Sheeza, 2013).

\section{Islamic Economics Case Studies in the World of Islam}

Born of the twentieth century, Islamic economics (IE) provides a new Islamic orthopraxy to help substantiate and unify the collective Muslim identity across borders while simultaneously reconciling tradition with modernity. Although this recent development in economics manifests Westernization under the guise of a "return to Islam" (Kuran, 2004), its function in identity politics for Muslims serves an important purpose in today's Islamic political agenda. Examination of the various forms of IE in nations such as Saudi Arabia, Iran, and Malaysia elucidates the differences in theory versus practice. This divergence highlights the Islamic market's shortcomings as an economic model and questionable success as a corollary to Muslim identity, but nonetheless its increasingly integral role in today's Islamic political landscape. 
The development of standard-setting bodies and global facilitators like the Accounting and Auditing Organization for Islamic Financial Institutions (AAOIFI), the Islamic Financial Services Board (IFSB), the International Islamic Financial Market (IIFM) and the Liquidity Management Centre (LMC) is providing recognition for Islamic finance and enhancing its credibility to both customers and regulators. Iran, Malaysia, and Saudi Arabia have been serving as its hub for about the last two decades. With the afore-said in mind and for the purpose of this paper, the present study presents the Islamic economics case studies obtainable in Iran, Malaysia and Saudi Arabia.

\section{The Islamic Republic of Iran}

Iran is one of the pioneers of Islamic finance. In 1983, four years after the revolution led by Ayatollah Khomeini overthrew the Shah, the Islamic government passed the Riba-Free Banking Act, forcing local banks to rebuild their business around Sharia-compliant products (Dettoni, 2015). The leaders of the Iranian revolution stressed the importance of restoring Islam's role in Iranian societal identity (Munawar \& David, 2002); with Islamic banking being one of many ways by which the Islamic Republic aimed to establish a universally Islamic society (Kuran, 2004). The Shah notoriously led a lavish lifestyle, and conventional banks were seen as exploiting society and spurring poverty. The new Islamic government made a point to emphasize austerity, and believed that Islamic banking, at least to an extent, should be consistent in restoring the centrality of Islamic orthopraxy in the lives of Iranian citizens. IE was a way for the new Islamic Republic of Iran to further establishing Islamic control throughout Iranian society.

Four years after the Islamic Revolution of 1979, the new Islamic government established the Riba-Free Banking Act, which created a national system of IE (Kuran, 2004). More than 30 years on, the Iranian banking industry remains completely regulated by Sharia law and are by far the world's largest center of Islamic banking. Yet its experience is unique within the global Islamic community, as it is inspired by Shi' ah jurisprudence, which often diverges from mainstream Sunni jurisprudence (Dettoni, 2015). The Iranian economy rest with a firm legislative and regulatory infrastructure that always starts from top echelon via the concept of Wilayatul Faghi (Guardianship of the Jurist) and rests upon defining the competences of the supreme authority in line with the theocratic tendencies, people's requirements and wishes as well as the development imperatives to define the modern economic and social sciences.

Years of economic isolation due to sanctions have led to a form of IE in Iran that differs greatly from the rest of the Islamic world. These differences have hindered the creation of a universal Islamic banking system. Many Sunni scholars believe Iranian Islamic institutions will continue to remain segregated from the rest of the Islamic financial market because of the lack of reliance on Sharia schools of thought (Kuran, 2004). However, Iranian analysts remain optimistic as Iranian banks move to create alternative Sukuk products (i.e. Islamic bonds), as well as negotiate the Iran nuclear deal, which will open Iranian markets and possibly lead standardization. Following the Islamic Revolution, Iran's banking system was transformed to be run on an Islamic interest-free basis. As of 2010 there were seven large government-run commercial banks. As of March 2014, Iran's banking assets made up over a third of the estimated total of Islamic banking assets globally. They totaled 17,344 trillion rials, or US\$523 billion at the free market exchange rate, using central bank data.

Iran, the only Muslim country besides Sudan where the entire financial industry is obliged to be consistent with the principles of Sharia law, accounts for more than 40 percent of the world's total Islamic banking assets. Trailing far behind is Saudi Arabia with 18.5 percent, Malaysia with 9.56 percent, and the UAE with 7.36 percent. However, years of isolation have prevented its bonds from reaching the international markets, leaving the leadership of the global Sukuk market to Saudi Arabia, and above all, Malaysia. Things may be approaching a turning point as the Islamic Republic and the P5+1 group (China, France, Russia, the United Kingdom, the United States plus Germany) appear closer than ever to a deal over Iran's nuclear development program. A deal would trigger a gradual removal of Western sanctions and reinstate Iran as a legitimate member of the global financial community. However, with Iran now seemingly closer than ever to an agreement with the West over its controversial nuclear development program, local financial institutions are poised to regain access to international markets and place their Sharia-compliant products among emerging market enthusiasts (Dettoni, 2015).

However, Iranian analysts remain optimistic as Iranian banks move to create alternative Sukuk products (i.e. Islamic bonds), as well as negotiate the Iran nuclear deal, which will open Iranian markets and possibly lead standardization. "This Iranian government led by Hassan Rohuani is very keen to integrate the country into the global economy," Ishrat Hussain, former governor of the Central Bank of Pakistan, told The Diplomat. 
"They have to catch up with the rest of the world. Now that the sanctions may be over, the government and the private sector have to do lot to rebuild the economy". Cash-strapped Iranian state and private companies are keen to tap the international debt market and address the shortage of hard currency they are facing as a result of years of crippling international sanctions. About 180 companies are considering Islamic bond sales in 2016, a Bloomberg report noted in April, quoting estimates from a local financial analyst. Foreign investors will be equally keen to chip in given Iran's economic potential based on its massive hydrocarbons resources and a domestic market of 77 million people. Iran featured among Goldman Sachs' "Next 11" most promising countries in 2007, before a new round of Western sanctions dragged down the entire economy ( Dettoni, 2015).

\section{Malaysia}

Following Malaysia's independence in 1957, the Malay government looked to create economic stability in a country reeling from war, as well as to firmly establish the Malaysian society upon Islamic ideals. Islamic banking was first introduced to Malaysia in 1963, with the formation of the Perbadanan Wang Simpanan Bakal-Bakal Haji (PWSBH), or Pilgrims Savings Fund Corporation, which allowed Muslims in Malaysia to save money interest-free in order to perform the hajj (pilgrimage). Established a decade later in 1976, the Islamic Economic Development Foundation of Malaysia combined amal (charity) and investment under Sharia guidance, an attempt by the Malaysian government to promote Islamic ideals of brotherhood while also spurring economic growth through inspiration to its predominantly Muslim populace . Not long after, the Maybank Islam Berhad was established in 1983 as the first Sharia-compliant bank in Malaysia, replacing all interest bearing transactions with Islamic alternatives. Today, Maybank ranks the highest for best Islamic institution in Asia (Kuran, 2004).

In the contemporary world, we have macro-level evidence of distributive justice and development. The trickledown theory (TDT) adopted in Malaysia during 1957-1970 failed miserably and resulted in the tragedy of 13thMay (1969) race riots in the country. Then the Malaysian government adopted a policy which applied the core value of Islam, i.e. justice with fairness that has contributed significantly to the country's miraculous achievement in the last three decades. Although the government could not fully apply the Shari'ah principles, it adopted a pragmatic policy (New Economic Policy) that had the twin objectives of eradicating poverty and restructuring society to ensure justice with fairness. This policy of higher growth with distributive justice emerged as a direct response to the failure of the growth alone development policy (TDT) pursued during the 1960s. Success at the macro-level did act as a contributory factor to compensate the failure of some institutions and values at the micro-level. Based on the principles laid down in the Holy Qur'an and the Sunnah of the Prophet, Muhammad (PBUH), the Islamic system played a strategic role in the development of human society from the second half of the seventh to the tenth century AD. The early Muslims excelled in all the fields of knowledge of their times, besides understanding and practicing the tenets of Islam (Ayub, 2007).

Malaysia's form of IE is quite unique compared to its Islamic counterparts. While countries such as Iran, Sudan, and Pakistan sought a complete Islamization of their banking systems, Malaysia instead established a "dual banking" system in which Islamic banks and conventional banks operate side-by-side, similar to Saudi Arabia (Kuran, 2004). This model was later adopted by Sudan and Pakistan, looking to Malaysia for their example. Today, Malaysia seeks to establish Kuala Lumpur as the world center for IE, with the data showing such efforts: Islamic banks currently compromise $20.7 \%$ of Malaysian banks and two-thirds of globally issued sukuks originate in Malaysia. As a result, Malaysia has been the subject of many case studies on the successful implementation of IE (Daromir, 2014).

\section{The Kingdom of Saudi Arabia}

Modern day IE began in Saudi Arabia in the 1970s with King Faisal as a result of the Saudis' attempt to create an international Islamic coalition. King Faisal carried out the coalition's message of pan-Arabism and panIslamism, and focused many resources towards IE. The Organization of Petroleum Exporting Countries (OPEC) was established by Saudi Arabia in 1960, and succeeded in not only bringing in vast wealth to participating nations, but also in helping to unify Muslim countries in the Middle East and North African region. In 1969, Saudi Arabia created the Organization of the Islamic Conference (OIC) in order to promote Islam on an international scale and unite the Islamic states. Furthermore, the Arab loss in the 1973 Yom Kippur War inspired re-Islamitization, leading OPEC to initiate its first oil embargo the same year. The earliest Islamic bank still in operation today is a private commercial bank that opened in Dubai in 1975. The OIC voted on 
the creation of the Islamic Development Bank, located in Saudi Arabia, which began activities the same year (Kuran, 2004). The Islamic Development Bank facilitated the transfer of petrodollars earned through OPEC post-embargo to Muslim countries through interest-free instruments (Ibid). These first Islamic banks were meant not only to establish an Islamic-focused banking method that outlawed the Qur'anic standard of usury, but were also a response to calls for Islamic ideals to be upheld throughout all sections and sectors of society.

Additionally, King Faisal saw Islamic banking as a way to control the invasion of Saudi Islamic ideas by the Muslim Brotherhood. During the persecution of the Muslim Brotherhood in Egypt under Gamal Nasser and Anwar Sadat, the Kingdom of Saudi Arabia provided money and refuge to many fleeing members. Muslim Brotherhood members even served as teachers for the newly formed madrasahs (schools) in Saudi Arabia. Because of their role in the Saudi education system, the Muslim Brotherhood began to gain leadership and control in Saudi Arabian society. By creating an Islamic financial institution run by the Kingdom, King Faisal reined in some of the influence garnered by the Muslim Brotherhood (Kuran, 2004). Also, King Faisal, although initially friendly with Reza Shah Pahlavi of Iran, began to see the Shah's modernization of Iran's military and dominance in the Middle East region as a threat both to Saudi security, and to the continuation of Islamic influence. Islamic banks in Saudi Arabia and beyond stood in contrast to the Shah's anti-Islamic military regime. IE furthered Saudi Arabia's goal of Islamic unification in the face of outside Western influence and threats to Islamic states.

Today, the Saudi Arabian model for IE is considered the baseline of orthopraxy for Muslim countries across the Middle East and South East Asia, as well as non-Muslim countries that have incorporated Islamic banks, such as the Bank of London and the Middle East and the American Finance House LARIBA. The basis for IE in Sunni countries such as Saudi Arabia relies on Sharia law established by the four schools of thought: $M a$ laki, Hanafi, Shafii, and Hanbali (Kuran, 2004). Islamic finance extends beyond its well-known characteristics: interest-free banking and the prohibition of investment in items or activities deemed un-Islamic, such as prostitution, gambling, pornography, pig farming and alcohol. In contrast to conventional loans, Islamic bank loans are confined to financing the purchase of physical assets, to which they have recourse in case of default.

\section{Conclusion and recommendations}

In conclusion, it's worthy of note that the future of the modern economies are expected to be better, particularly if the instability that now prevails in the international financial system continues to accentuate and leads to a realization that it cannot be removed by making cosmetic changes in the system but rather by injecting into the system greater market discipline. This discipline is ingrained in Islamic finance principles. The innovation brought about by the structuring of Islamic economics and its financial products would contribute to the creation of new asset class which will be available to customers of all faiths. The introduction of Islamic finance models such as the Mudarabah, Murabaha, Sukuk, and Istisna'a which have been tried and tested in other countries would further strengthen the financial system in both conventional and Islamic economies thereby creating risk diversification against possible and future financial crisis. Hence, the introduction of a new asset class from Islamic perspective can further create competition within the financial system and competition will drive the market and the economy. In this regards, Islamic Finance would significantly contribute to financial stability in such economies. This is because the principle of Islamic finance negates all the factors which led to the global financial meltdown in the 2008. The overall recommendation of this paper is that, once Islamic finance as an ethical finance is properly put into practice in our economies, more people would apply for it, whereat such economies might stand to take advantage of the beneficial social goals of Islamic economics in line with the trends, people's needs and aspirations as well as the development imperatives to define the modern economic and social sciences.

\section{References}

1. Abdulkadir, A.R. \& Murtala, B.M. (2016). An Empirical Appraisal of Conventional and Islamic Banking Systems in Nigeria: Who does the cup fit? Sokoto Journal of Management Studies, Special Conference Edition, Vol. 11(1), October. Pp. 11-36

2. Ali, S.S. (2015). Islamic economics and social justice essays on theory and policy. In H,A. El-Karanshawy et al (eds.), Islamic Economic: Theory, Policy and Social Justice. Doha, Qatar: Bloomsbury Qatar Founadation.

3. Ayub, M. (2007). Understanding Islamic finance. West Sussex: John Wiley \& Sons Ltd.

4. Budiarto, R., Wardhana, A.R. \& Prastowo, A. (2016). Implementation of Islamic Economics in Indonesia by Developing Green Economy through Renewable Energy Technologies. A Conference paper presented 
@ Gadjah Mada International Conference on Islamic Economics and Development, @ Gadjah Mada University, Indonesia. Available online at: https://www.researchgate.net/publication/303235481_Implementation of Islamic Economics in Indonesia By Developing_Green Economy through Renewable_Energy T echnologies. Retrieved online $28^{\text {th }}$ March, 2018.

5. Daromir, R. (2014). Economy in Practice: Islamic finance and the problem of market reason. Journal of the American Ethnological Society, 2014; Volume 41, Number. 1, P. 110-127.

6. Dettoni, J. (2015). Iran and the Islamic Finance Crown. Available online at: https://thediplomat.com/2015/06/iran-and-the-islamic-finance-crown/. Retrieved online $\quad 28^{\text {th }}$ March, 2018

7. Folami, M. (2011). Cure or Curse? It is working in a number of countries but the controversy generated by the introduction of the Islamic Banking System in Nigeria is giving cause for worry. National Review, Vol. 9, No. 3. October 2011. Pp. 18-19

8. Islamic Banker Limited (2018). Islamic Economy: Three-Sector Model. Available online at: https://islamicbanker.com/education/islamic-economy-three-sector-model. Retrieved online $28^{\text {th }}$ March, 2018

9. Kuran, T. 2004. Islam \& Mammon: The Economic Predicaments of Islamism. Third printing and first paperback printing ed. Princeton: Princeton University Press, 89.

10. Lawal, R.S., Wadata, M.H., \& Umar, S.I. (2016). Role of Islamic microfinance in poverty alleviation and economic self-reliance. Readings in Management Studies. Vol. 5, October.

11. Munawar, I. \& David, T. L. (2002). Islamic Banking and Finance: New Perspectives on Profit-Sharing and Risk, 2002, eds. Cheltenham: Edward Elgar Publishing Limited, 1.

12. Mustapha, N.T. \& Muhammad, S.U. (2016). An Assessment of Islamic Financing of Ja'iz Bank in Nigeria. Sokoto Journal of Management Studies, Vol. 11(1).

13. Obaidullah,M. (2005). Islamic financial services. Islamic Economic Research Centre, Occasional Paper 158, King Abdulaziz University, Jeddah, Saudi Arabia.

14. Omar, M.A. (2015). Preface. In H,A. El-Karanshawy et al (eds.), Islamic Economic: Theory, Policy and Social Justice. Doha, Qatar: Bloomsbury Qatar Foundation.

15. Sheeza, A. (2013). How Islamic finance and a more ethical capitalism go hand-in-hand. Available online at: https://www.theguardian.com/social-enterprise- network/2013/jan/24/islamic-finance-ethical-capitalism-social-enterprise. Retrieved online $28^{\text {th }}$ March, 2018.

16. Siddiqui, S.H. (2016). Islamic Banking: True Modes of Financing. Available at: www.islamic-banking.com. Retrieved online $28^{\text {th }}$ March, 2018. 